\title{
Development and validation of a scale on teacher's competence in action research
}

\author{
Cortes, Sylvester $\bowtie$ \\ Cebu Technological University, Philippines (sylvestertcortes@gmail.com) \\ Pineda, Hedeliza \\ Cebu Technological University, Philippines (hedeliza.pineda@ctu.edu.ph)
}

Geverola, Immar Jun

Alaska Night High School, Cebu City Division, Department of Education, Philippines (immarjunrobledogeverola@gmail.com)

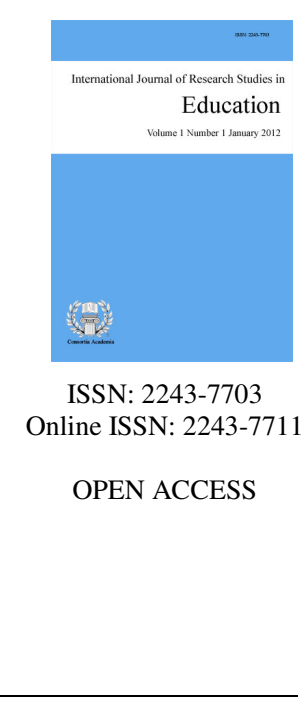

Received: 9 July 2020
Available Online: 28 September 2020

Revised: 9 August 2020

Accepted: 18 September 2020

\section{Abstract}

The Philippine Qualifications Framework (PQF) directs the Commission on Higher Education (CHED) to lay out policies, standards, and guidelines for higher education academic programs, and help basic education teachers by providing them with appropriate professional development (PD) programs. One of the programs referred is training them to reflect on their professional practices by means of action research (AR). However, issues concerning impact evaluation of these PD programs have been raised. This study thus aims to develop a valid and reliable self-report scale to measure competence of teachers in conducting an AR project as one of the tools for impact evaluation. To do so, a scale called TCAR was developed according to constructs of Johnson's (2008) Model of AR. The validity and reliability of the scale were established by examining responses of 166 AR practitioners who are teachers from basic education program. Factor Analysis was performed and confirmed the hypothesized model of AR of which the percentage of variance explained by the scale is 78.161. It retained 54 items which are distributed in seven subscales generated, namely: analyzing and presenting AR data, reflecting on and communicating results, planning an AR project, integrating ethics, selecting topic for professional growth, integrating technology in writing literature, and integrating technology in analyzing data. The Cronbach's alpha was also computed as a measure of internal consistency for the whole scale which results to .988. Thus, findings of this study provide significant evidence for the validity and reliability of TCAR.

Keywords: action research; action research practitioners; competence; scale development; self-report 


\section{Development and validation of a scale on teacher's competence in action research}

\section{Introduction}

There is a great deal of educational reforms around the world as revealed by a number of comparative studies being done (Levin, 2001). These reforms direct the roles of schools and have profound impact to teachers' professional lives (Madden, Wilks, Maoine, Loader, \& Robinson, 2012). This is because teachers should effectively respond in these systemic changes otherwise these can actually be seen as "deforms" which will result to increasing impoverishment and misery to them, and the educational community (Arnove, 2005). In this regard, global interest in promoting professional development (PD) programs has been acknowledged as key mechanism to mobilize these educational reforms (Bautista \& Ortega-Ruiz, 2015). One of the programs referred is training teachers to reflect on their practices through action research. It is a form of enquiry which enables a practitioner to investigate, reflect, and eventually improve his work practices, thus, a popular form of professional learning for teaching, but is now applied across other professions (McNiff \& Whitehead, 2006).

So far, there are three teacher development programs relating to AR since 2010 have been documented globally (i.e. Cullen, Akerson, \& Hanson, 2010; Hathorn \& Dillon, 2018; Paredes-Chi \& Castillo-Burguete, 2018). In the Philippines, PD programs about AR are not well documented although several needs-assessments have been reported (e.g. Morales et al., 2016; Ulla, Barrera, \& Acompanado, 2017; Cortes, 2019). The transition of the country's basic education curriculum has put the national and local initiatives on teacher trainings about AR into our peripheral vision. Nonetheless, the attention on AR was put into renaissance when the country's Department of Education released several orders to promote and strengthen the culture of research in basic education program in order to build their policies and decisions anchored on evidences. The most recent orders were in 2017 which establishes Research Management Guidelines (RMG) (Department of Education, 2017) and which adopts and implements the Philippine Professional Standards for Teachers (PPST) (Department of Education, 2017). The Philippine Higher Education Institutions are also with these national efforts per mandate of the Philippine Qualifications Framework (PQF) to help the basic education system by providing timely and appropriate PD programs.

However, issues concerning impact evaluation of these programs have been raised. While we have acknowledged and adopted a plethora of analytical frameworks (e.g. Guskey, 2002; Clarke \& Hollingsworth, 2002; Desimone, 2009) to guide the process in designing, analyzing, and evaluating PD programs, these only provide us potential variables or measures to evaluate which include but not limited to teachers' beliefs, attitudes, knowledge and skills. With these, the PD models might have universal applicability, but these tend be too generic, conceptual, or processual in focus. In the context of teacher training on AR, Evans' (2012) concept of researcher development is regarded as the most appropriate analytical framework for impact evaluation. This model identifies componential structures of the three principal domains or components of researcher development, namely: attitudinal, intellectual, and behavioral. These subcomponents, however, have to be operationally defined specific to the topic being trained because some competencies in AR, for an instance, are distinct with other research methods in the spectrum of traditional educational research. It also holds true to other subcomponents such as the processual, procedural, productive, etc. This study thus aims to operationally define the professional competences in the context AR by developing a valid and reliable self-report scale. The scale intends to measure competential change, one form of researcher development which involves increase of or enhancement of research-related skills and competences, such as the development or refinement of writing, analytical or presentation skills (Evans, 2012). Although this scale will only evaluate one impact of PD program in AR, but this could initiate development of scales for the rest of the componential structures of researcher development in future researches. 


\section{Methods}

\subsection{Participants}

The researchers recruited teachers from elementary and secondary schools in one of the provinces in Central Visayas, Philippines to test the psychometric properties of TCAR. These teachers have previous trainings and engagement in designing at least an AR project. Prior to the recruitment, a transmittal letter indicating the nature and purpose of the study was sent to the schools' division superintendent as a mode of obtaining consent. Upon approval, the questionnaires were distributed to 187 teachers and 166 were returned, resulting to response rate of $88.70 \%$. The preliminary attachments of these questionnaires were letter of invitation to participate in the survey and informed consent. The latter explains purpose and background of the study, procedures, extent of confidentiality, benefits, and that their participation was voluntary.

\subsection{Instrument Development}

TCAR was developed following the practical guidelines of Barry, Chaney, Stellefson, and Chaney (2011). The scale thus underwent multiple stages of development and validation which involved (a) outlining the construct(s), (b) developing scale design and structure, (c) generating sample items, and (d) pretesting the scale. These steps characterize the nature of sequential exploratory mixed methods research design which integrates both qualitative and quantitative data with the former being collected initially.

Outlining the Constructs - The initial and critical phase in scale development is to outline the domains or context of the constructs. Note that Evans' (2012) componential structure of researcher development, as shown in Figure 1, may provide these constructs which can be translated into components of researcher development (i.e. behavioral, attitudinal, and intellectual) but each component has further dimensions or subcomponents which make up the constructs. For an instance, behavioral component is composed of processual, procedural, productive, and competential dimensions. However, competential dimension alone in the context of research involves competence in developing a research question, choosing appropriate research design, data collection techniques, analysis, and among others. These competences do not essentially make up other dimensions within behavioral component. To identify these AR competences, an AR model was adopted to identify the steps or process of the research method, and eventually become the basis of the constructs of the scale. This is because the steps also set and describe the relevant competences. In this regard, Johnson's (2008) AR model which is reflected in his book entitled "A Short Guide to Action Research" was used as basis to outline the constructs of the scale. This model, as shown in Figure 2, is a cyclical, continuous, and iterative process of planning, acting, developing, and reflecting. Its strength rests on the apparent display of prescriptive processes which should transpire in all stages of AR, which is from problem conceptualization to professional reflection. Each of this stage eventually directs the pool of items to be created, but their operational definition, reflected in Table 1, have to be delineated as basis for creating the items.

Developing Scale Design and Structure, and Generating Items - The researchers used literature review as a deductive approach in initially generating items within the competences of AR. The review generated 61 items which were distributed in four stages of AR: planning (14 items), acting (29 items), developing (6 items), and reflecting (12 items). All items were worded positively to avoid reverse coding and scoring. Each item was rated on a five-point scale, with 1 as limited, 2 as basic, 3 as proficient, 4 as advanced, and 5 as expert. Although a comprehensive and broad number of items were developed in this stage, the following psychometric tests will eventually remove the items that do not capture the essence of the a priori constructs. 


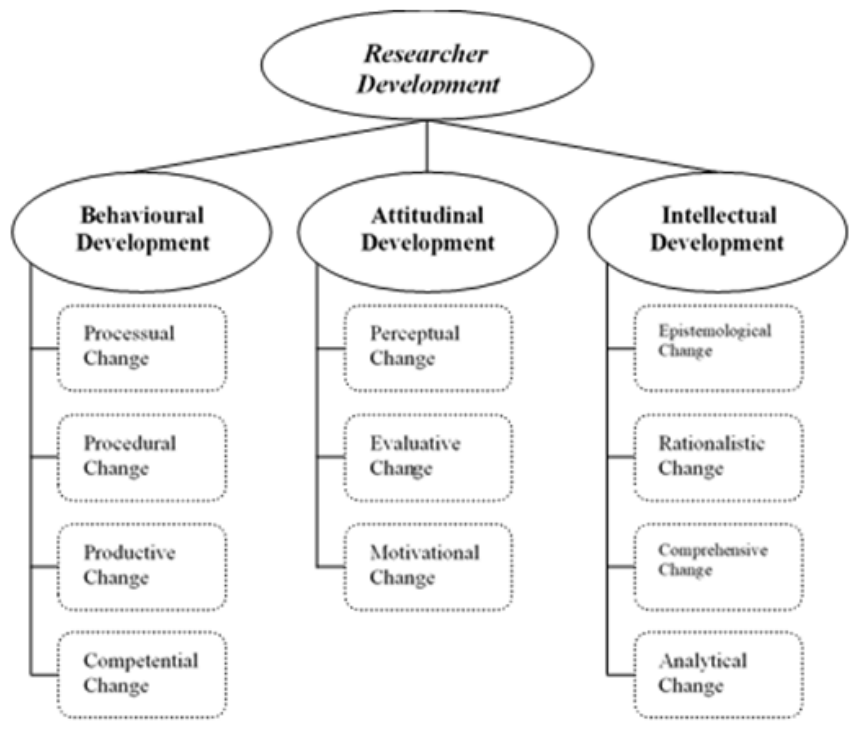

Figure 1. Componential structure of researcher development (Evans, 2012)

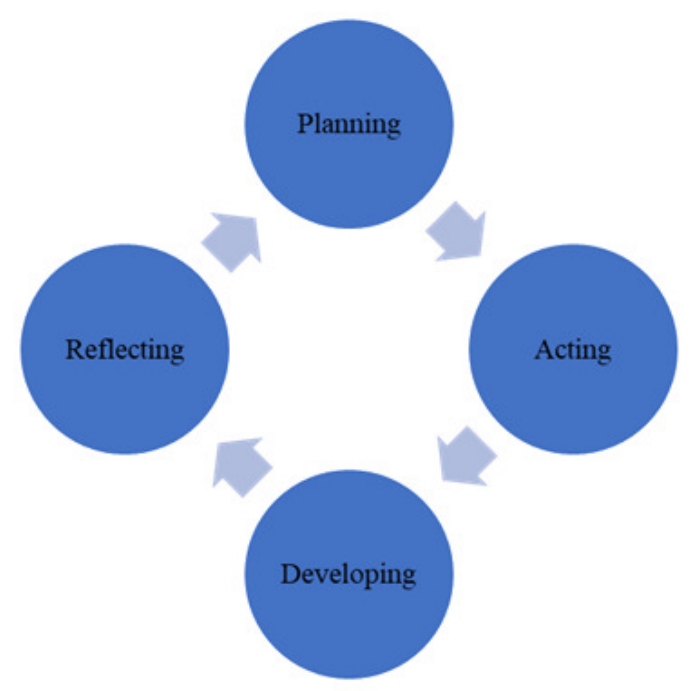

Figure 2. Johnson's (2008) AR Model

Table 1

Table of Specification for Scale Construction

\begin{tabular}{ll}
\hline \multicolumn{1}{c}{ Constructs } & \multicolumn{1}{c}{ Operational definition } \\
\hline Planning & $\begin{array}{l}\text { An initial stage in AR characterized by identifying and limiting a topic, } \\
\text { reviewing and writing related literature. }\end{array}$ \\
Acting & $\begin{array}{l}\text { The collection and analysis as well as reporting of results } \\
\text { The stage to which a teacher reflects on his AR journey. The teacher writes } \\
\text { an action plan as a proof of his professional reflection. Finally, it is in this } \\
\text { stage which the teacher communicates his results in written or oral form. }\end{array}$ \\
\hline
\end{tabular}

Reducing the Items - The panel of experts were composed of one division education specialist in DepEd whose one of the assignments involve training teachers on AR, a graduate student with interest and publications in research instrumentation, and a professor from Normal school who conducts CPD programs in AR. They determined the content validity of the items in the scale by using Aiken's Validity Index (AI) to which each item 
was rated on a four-point Likert scale ( 1 = irrelevant, $2=$ needs modification, $3=$ relevant, $4=$ strongly relevant $)$ to avoid neutral midpoint. After the calculation, the AVI of all items range from 0.78 to 1.00 , hence, all are included as the values are classified excellent (Terwee et al., 2007). Subsequently, the scale was purposively administered to 187 teachers of which 166 were returned without missing data. This sample size is considered adequate because 150 cases for exploratory factor analysis (EFA) and 100 for confirmatory factor analysis (CFA) are considered enough provided the inter-item correlation is practically strong (Guadagnoli \& Velicer, 1988). In this case, the inter-item correlation ranges from .564 to .864 of all the items. In addition, sampling size adequacy was established by calculating Kaiser-Meyer-Olkin (KMO) which results to .954 and Bartlett's Test of Sphericity which is significant $(p<.000)$. The scale was then available for principal component axis factoring to estimate the factorability of the correlation matrix and to determine the number of factors. The factors with Eigen values greater than 1.0 were included. Eventually, the resulting number of factors went through principal components and maximum likelihood analysis through Varimax rotation with Kaiser Normalization as its rotation method. Only items which criterion loading are .5 and above were included in the final factors for pragmatic reason. Finally, Cronbach's alpha was determined to establish the internal consistency of the scale and its factors.

\section{Results and Discussion}

The factor analysis examined 61 items of the scale. Seven of these items failed to reach the criterion loading set at .50 , thus, removed. Meanwhile, three items crossload twice to two factors. The items referred are no. 30 and 31 which both crossload in Factor 6 and Factor 1 but eventually assigned to the latter. Item 35 crossloads to Factor 2 and Factor 3 but assigned to the former. The pragmatic reason for assigning these items to specific factor rests on their apparent alignment or consistency with the other items of the factor. As a result, the factor analysis only retains 54 items which are distributed in seven factors, namely: analyzing and presenting AR data, reflecting on and communicating results, planning an AR project, integrating ethics, selecting topic for professional growth, integrating technology in writing literature, and integrating technology in analyzing data. The total percentage of variance explained by these seven factors is 78.161 .

Factor 1 accumulates 61.573 percent of the variance from the total and loads 13 items. The items aggregating in this factor explore teacher's self-report competence to collect, analyze, and present AR data which is identified as the acting stage of Johnson's (2008) AR model, thus named as analyzing and presenting AR data factor. Factor 2 clusters items which investigate teacher's competence in developing an action plan, a period when a teacher puts his professional reflection on the AR process into writing. Although there are 13 items which load in this factor including the items which assess competence to communicate results, the percentage of variance explained is 4.658. This draws a significant margin from Factor 1. As the factoring moves to Factor 3, the combined percent of variance of the items drops to 3.274 but loads 11 items. These items report on teacher's self-perceived competence to design an AR project which is characterized by preliminary activities when doing an AR such as identifying and limiting a topic and reviewing related literature. In this regard, the factor is named planning an AR project.

The items on integrating ethics load in Factor 4 which explains 2.780 and loads eight items. These items were originally assigned and distributed in four stages of action research but eventually grouped into one factor, hence, can be classified as latent factor. The purpose of these items is to let the teacher assess his perceived competence in the ethical guidelines of AR. Factor 5 are items exploring competence on selecting topic for professional growth. In other words, these topics are those relevant in teaching profession. This factor explains 1.365 percent of the variance and loads four items. Finally, Factor 6 and Factor 7 are loading items which evaluate competence to utilize technology in writing literature and analyzing data, respectively. The former explains 1.166 percent of the variance and loads two items while the latter explains 1.053 percent of the variance and loads three items. These items were originally assigned in any of the stages of AR but clustered in separate factors.

The scale reliability as determined by Cronbach's alpha ranges from .855 to .972 within subscales and .988 
Cortes, S., Pineda, H., \& Geverola, I. J.

for the entire scale. All of these reliability coefficients fall into the minimum standards and are classified "very good" (Nunnally, 1978). These results confirm that TCAR has an ideal stability.

\section{Table 2}

Teacher's competence in action research survey items $(N=166)$

\begin{tabular}{|c|c|c|c|c|}
\hline \# & Factors/Items & Communalities & Mean & SD \\
\hline & $\begin{array}{l}\text { Factor 1. Analyzing and Presenting Action Research Data } \\
(\alpha=.972,13 \text { items, } \% \text { variance }=61.573)\end{array}$ & & & \\
\hline 19 & $\begin{array}{l}\text { I can align appropriate statistical test with parametric and nonparametric data to } \\
\text { address issues of validity in quantitative action research studies. }\end{array}$ & .525 & 2.01 & .814 \\
\hline 20 & I can determine which analysis suits to qualitative data. & .624 & 2.09 & .859 \\
\hline 21 & I can develop a data collection plan. & .639 & 2.10 & .814 \\
\hline 22 & I can summarize collected data in a dependable and accurate manner. & 682 & 2.07 & .885 \\
\hline 23 & I can interpret the underlying meaning or the implication of the data. & .594 & 2.05 & .777 \\
\hline 24 & $\begin{array}{l}\text { I can perform preliminary and iterative steps involving reading, describing, and } \\
\text { classifying research data before proceeding to data analysis. }\end{array}$ & .571 & 2.09 & .823 \\
\hline 25 & I can identify techniques involved in qualitative data analysis. & 699 & 2.03 & .766 \\
\hline 26 & $\begin{array}{l}\text { I can analyze quantitative data regardless if the test involves descriptive or } \\
\text { inferential. }\end{array}$ & .721 & 1.99 & .828 \\
\hline 27 & I can identify emerging themes in an inductive analysis of qualitative data. & .658 & 1.95 & .792 \\
\hline 28 & $\begin{array}{l}\text { I can analyze both quantitative and qualitative data in mixed-method research } \\
\text { deigns. }\end{array}$ & 699 & 2.01 & .794 \\
\hline 29 & I can create a coherent story from all the data collected. & .690 & 2.01 & .722 \\
\hline 30 & I can make visual display for the reader to easily understand information. & .529 & 2.15 & .836 \\
\hline \multirow[t]{2}{*}{31} & I can present qualitative data in graphs, charts and networks when necessary. & .544 & 2.15 & .864 \\
\hline & $\begin{array}{l}\text { Factor 2. Reflecting on and Communicating Results } \\
(\alpha=.970,13 \text { items, } \% \text { variance }=4.658)\end{array}$ & & & \\
\hline 34 & $\begin{array}{l}\text { I can identify the distinction between an action plan and the action research process } \\
\text { itself. }\end{array}$ & .531 & 2.03 & .849 \\
\hline 35 & I can discuss the purpose of an action plan. & .533 & 2.10 & .871 \\
\hline 36 & I can identify the basic components of an action plan. & .617 & 2.03 & .842 \\
\hline 37 & I can design an action plan following the "Steps to Action Chart" format. & .643 & 1.92 & .797 \\
\hline 38 & $\begin{array}{l}\text { I can work with an array of people to develop action plan depending on the scope } \\
\text { of action research effort. }\end{array}$ & .600 & 2.07 & .798 \\
\hline 39 & I can write the action research report in a scholarly manner. & .507 & 1.98 & .746 \\
\hline 40 & $\begin{array}{l}\text { I can formally write an action plan as a complete report for the action research } \\
\text { project when considered for publication in a professional journal. }\end{array}$ & .559 & 1.95 & .749 \\
\hline 41 & $\begin{array}{l}\text { I am aware on the guidelines in academic writing agreed-upon conventions of style } \\
\text { (e.g. Publication Manual of the American Psychological Association). }\end{array}$ & .642 & 1.93 & .803 \\
\hline 42 & $\begin{array}{l}\text { I am aware on the basic organizational structure for formatting an action research } \\
\text { report. }\end{array}$ & .673 & 1.96 & .754 \\
\hline 43 & $\begin{array}{l}\text { I am aware on the fundamental submission guidelines to a research journal when } \\
\text { considering an action research project for publication. }\end{array}$ & .563 & 1.91 & .729 \\
\hline 44 & I can identify which journals are tagged as credible and predatory. & .542 & 1.90 & .760 \\
\hline 46 & I can disseminate results of action research in journals and conferences. & .602 & 1.92 & .797 \\
\hline 47 & $\begin{array}{l}\text { I can present information without revealing confidential details regarding } \\
\text { participants or location. }\end{array}$ & .526 & 1.96 & .758 \\
\hline
\end{tabular}

\section{Factor 3. Planning an Action Research Project}

$(\alpha=.960,11$ items, \% variance $=3.274)$

4 I can narrow the research topic to put it in a researchable concept.

5 I can state research questions in common language.

6 I can ensure that the topic I will be working on is grounded in the realities of the

school.

8 I can identify what has been done in previous studies and the gaps when choosing a topic.

9 I can identify underlying assumptions of previous authors on their research questions.

11 I can evaluate my sources when conducting literature search and review.

12 I can track and write references of the literature used in the review.

14 I am aware on the usefulness and limitations of various qualitative data collection tools.

16 I can conduct research in a systematic and disciplined manner.

I can determine appropriate data sources to establish data triangulation.

18 I am aware on the usefulness and limitations of various quantitative data collection tools. 
Table 2 ...continued

\begin{tabular}{|c|c|c|c|c|}
\hline \# & Factors/Items & Communalities & Mean & $\mathrm{SD}$ \\
\hline & $\begin{array}{l}\text { Factor 4. Integrating Ethics in Action Research } \\
(\alpha=.953,8 \text { items, } \% \text { variance }=2.780)\end{array}$ & & & \\
\hline 49 & I can write an assent form. & .502 & 2.08 & .758 \\
\hline 50 & I can write letter of consent to parents or legal guardians. & .665 & 2.33 & .896 \\
\hline 51 & $\begin{array}{l}\text { I know the guidelines in securing consent from my immediate head and teacher } \\
\text { researchers. }\end{array}$ & .686 & 2.18 & .869 \\
\hline 52 & $\begin{array}{l}\text { I can examine ethical slippages such as concealment and exaggeration when } \\
\text { analyzing data. }\end{array}$ & .580 & 2.02 & .786 \\
\hline 53 & I can provide information in the right way to participants. & .628 & 2.19 & .852 \\
\hline 54 & I can present and disseminate findings in line with ethical guidelines. & .643 & 2.15 & .864 \\
\hline 55 & $\begin{array}{l}\text { I can identify ethical issues which may arise ahead in an action research project } \\
\text { (e.g. research topic, method, design of instruments, archiving, etc.). }\end{array}$ & .697 & 2.23 & .885 \\
\hline \multirow[t]{2}{*}{56} & $\begin{array}{l}\text { I can apply the basic principles of ethical research which are stipulated in various } \\
\text { codes and guidelines (e.g. The Belmont Report, 1979). }\end{array}$ & .747 & 2.19 & .885 \\
\hline & $\begin{array}{l}\text { Factor 5. Selecting Topic for Professional Growth } \\
(\alpha=.855,4 \text { items, } \% \text { variance }=2.238)\end{array}$ & & & \\
\hline 1 & I can develop a research proposal which support my professional development. & .593 & 1.99 & .798 \\
\hline 2 & $\begin{array}{l}\text { I can choose questions which interest my teaching colleagues, counselors, and } \\
\text { administrators. }\end{array}$ & .710 & 2.21 & .761 \\
\hline 3 & $\begin{array}{l}\text { I know how to choose list of topics which are of interest to me before selecting the } \\
\text { one. }\end{array}$ & .656 & 2.28 & .899 \\
\hline \multirow[t]{2}{*}{7} & I can take literature search and review on my proposed topic. & .548 & 2.24 & .825 \\
\hline & $\begin{array}{l}\text { Factor 6. Integrating Technology in Writing Literature } \\
(\alpha=.886,2 \text { items, } \% \text { variance }=1.912)\end{array}$ & & & \\
\hline 60 & $\begin{array}{l}\text { I can use search engines to explore internet sites which will build my review of } \\
\text { related literatures. }\end{array}$ & .669 & 2.33 & .870 \\
\hline \multirow[t]{2}{*}{61} & I can use technology when doing bibliographical entries in Microsoft Word. & 699 & 2.31 & .933 \\
\hline & $\begin{array}{l}\text { Factor 7. Integrating Technology in Analyzing Data } \\
(\alpha=.909,3 \text { items, } \% \text { variance }=1.727)\end{array}$ & & & \\
\hline 57 & I can operate computer software in analyzing qualitative data (e.g. NVivo 10.0). & .824 & 1.92 & .824 \\
\hline 58 & I can operate computer software in analyzing quantitative data (e.g. SPSS). & .813 & 1.90 & .818 \\
\hline 59 & I can operate software programs for analyzing mixed-method data (e.g. Dedoose). & .738 & 1.80 & .735 \\
\hline
\end{tabular}

\subsection{Implications for teacher training practices}

Findings from this study provides us a valid and reliable self-report scale which can examine teacher's self-perceived competence in AR. Hence, one of the new contributions of the present study is to provide a quantitative scale which can assess teacher's competence held and competential changes, respectively, before and after a teacher will undergo a professional development program relating to AR. The scale specifically lays out necessary competences which are stated into items. Hence, if used as a tool for needs assessment, AR trainors may be guided on which specific competences need to be focused and improved by the teachers if they are planning for a professional training. In addition, the current study may also have implications for training policies of the Philippine Department Education, a government agency responsible for ensuring quality in basic education program. Currently, the department's research management guidelines (RMG) has a unified framework in the quality evaluation of AR proposals proposed by their teachers but it has not laid out an evaluation framework for training effectiveness on AR. Then, this developed scale may be integrated into the department's RMG as one of the tools which will evaluate perceived needs of the teachers in AR. Finally, this study may also have implications for pre-service teacher trainings. The 2017 policies, standards and guidelines for both elementary and secondary education integrated AR as a content course. In this regard, the developed scale may be used by the course professor to examine the needs of pre-service teachers in AR and evaluate their developments after taking the course. 


\section{Conclusion}

The findings of this study reveal TCAR as a valid and reliable self-report scale. It operationally defines the specific competences in action research, namely: analyzing and presenting AR data, reflecting on and communicating results, planning an AR project, integrating ethics, selecting topic for professional growth, integrating technology in writing literature, and integrating technology in analyzing data. These competences are essential in facilitating the evaluation of needs and professional development of teachers, respectively, who will undertake and undertook a professional development program in AR. To our knowledge, this is the first on the literature that one of Evans' components of researcher development is defined in the context of a quantitative self-perceived scale. In addition, this scale will eventually initiate the development and validation of other scales for the rest of the componential structures of researcher development in the context of AR in future researches. In the meantime, the scale can be used by professionals who train teachers on AR and by university lecturers who teach pre-service teachers on $\mathrm{AR}$ when evaluating competential needs and competential changes for an $\mathrm{AR}$ professional development program and AR course of teachers and students. TCAR is relevant beause effective professional development programs will rely on sound empirical data from needs assessment and impact evaluation.

\section{References}

Arnove, R. F. (2005). To what ends: Educational reform around the world. Indiana Journal of Global Legal Studies, 12(1). https://doi.org/10.2979/gls.2005.12.1.79

Barry, A. E., Chaney, B. H., Stellefson, M. L., \& Chaney, D. (2011). So you want to develop a survey: practical recommendations for scale development. American Journal of Health Studies, 26(1), 97-105.

Bautista, A., \& Ortega-Ruiz, R. (2015). Teacher professional development: International perspectives and approaches. Psychology, Society, \& Education, 7(3), 240-251. https://doi.org/10.25115/psye.v7i3.1020

Clarke, D., \& Hollingsworth, H. (2002). Elaborating a model of teacher professional growth. Teaching and Teacher Education, 18(8), 947-967. https://doi.org/10.1016/S0742-051X(02)00053-7

Cortes, S. T. (2019). Needs assessment on action research competencies of teacher-researchers in Surigao del Sur, Philippines. Journal of Education Naresuan University, 21(4), 1-19.

Cullen, T. A., Akerson, V. L., \& Hanson, D. L. (2010). Using action research to engage K-6 teachers in nature of science inquiry as professional development. Journal of Science T eacher Education, 21(8), 971-992. https://doi.org/10.1007/s10972-010-9218-8

Department of Education. (2017). National adoption and implementation of the Philippine Professional Standards for Teachers (PPST). https://www.deped.gov.ph

Department of Education. (2017). Research Management Guidelines. Retrieved from www.deped.gov.ph

Desimone, L. M. (2009). Improving impact studies of teachers' professional development: Toward better conceptualizations and measures. Educational Researcher, 38(3), 181-199. https://doi.org/10.3102/0013189X08331140

Evans, L. (2012). Leadership for researcher development: What research leaders need to know and understand. Educational Management Administration \& Leadership, 40(4), 423-435. https://doi.org/10.1177/1741143212438218

Guadagnoli, E., \& Velicer, W. F. (1988). Relation of sample size to the stability of component patterns. Psychological Bulletin, 103(2), 265-275. https://doi.org/10.1037/0033-2909.103.2.265

Guskey, T. R. (2002). Professional development and teacher change. Teachers and Teaching: theory and practice, 8(3), 381-391. https://doi.org/10.1080/135406002100000512

Hathorn, C., \& Dillon, A. M. (2018). Action research as professional development: Its role in education reform in the United Arab Emirates. Issues in Educational Research, 28(1), 99-119.

Johnson, A. P. (2008). A short guide to action research (3rd ed.). Boston: Allyn and Bacon.

Levin, B. (2001). Conceptualizing the process of education reform from an international perspective. Education Policy Analysis Archives, 9(14), 1-17. https://doi.org/10.14507/epaa.v9n14.2001 
Madden, J., Wilks, J., Maoine, M., Loader, N., \& Robinson, N. (2012). Journeying together: Understanding the process of teacher change and the impacts on student learning. Journal of Educational Administration, 40(2), 19-36.

McNiff, J., \& Whitehead, J. (2006). All you need to know about action research. The Cromwell Press Ltd.

Morales, M. P. E, Abulon, E. L. R., Soriano, P. R., David, A. P., Hermosisima, M. V. C., \& Gerundio, M. G. (2016). Examining teachers' conception of and needs on action research. Issues in Educational Research, 26(3), 464-489.

Nunnally, J. C. (1978). Psychometric theory (2nd ed.). McGraw-Hill.

Paredes-Chi, A. A., \& Castillo-Burguete, M. T. (2018). Is participatory action research an innovative pedagogical alternative for training teachers as researchers? The training plan and evaluation for normal schools. Evaluation and Program Planning, 68, 176-184. https://doi.org/10.1016/j.evalprogplan.2018.03.007

Terwee, C. B., Bot, S. D. D., de Boer, M. R., van der Windt, D. A. W. M., Knol, D. L., Dekker, J., Bouter, L.M., de Vet, H. C. W. (2007). Quality criteria were proposed for measurement properties of health status questionnaires. Journal of Clinical Epidemiology, 60(1), 34-42. https://doi.org/10.1016/j.jclinepi.2006.03.012

Ulla, M. B., Barrera, K. I., \& Acompanado, M. M. (2017). Philippine classroom teachers as researchers: Teachers' perceptions, motivations, and challenges. Australian Journal of Teacher Education, 42(11), 52-64. https://doi.org/10.14221/ajte.2017v42n11.4 
Cortes, S., Pineda, H., \& Geverola, I. J.

86 Consortia Academia Publishing (A partner of Network of Professional Researchers and Educators) 